BACKGROUND: Macrolide antibiotics such as erythromycin and roxithromycin (RXM) have an anti-inflammatory effect that may account for their clinical benefit in the treatment of chronic airway inflammatory diseases. However, the precise mechanism of this anti-inflammatory effect is not well understood. Purpose: The influence of RXM on matrix metalloproteinase (MMP)-9 production from neutrophils in response to lipopolysaccharide (LPS) stimulation was examined in vitro.

Methods: Neutrophils prepared from normal human peripheral blood $\left(1 \times 10^{5}\right.$ cells $\left./ \mathrm{ml}\right)$ were treated with various concentrations of RXM for $1 \mathrm{~h}$, and then stimulated with $1.0 \mu \mathrm{g} / \mathrm{ml}$ of LPS in the presence of the agent for $24 \mathrm{~h}$. MMP-9 and tissue inhibitor of metalloproteinase (TIMP)-1 levels in culture supernatants were examined by enzyme-linked immunosorbent assay.

Results: Addition of RXM at more than $5.0 \mu \mathrm{g} / \mathrm{ml}$ into cell cultures caused significant suppression of MMP-9 production, which was increased by LPS stimulation. However, the ability of cells to produce TIMP-1 was not affected by RXM treatment, even when the cells were cultured in the presence of agent at $10.0 \mu \mathrm{g} / \mathrm{ml}$. We then examined the influence of RXM on transcriptional factor, nuclear factor- $\kappa B$ and activator protein (AP)-1 activation by LPS stimulation. RXM exerted suppressive action on NF-KB (P50 and P65) activation when the cells were cultured for $4 \mathrm{~h}$ at more than $5.0 \mu \mathrm{g} / \mathrm{ml}$ of the agent. RXM at more than $2.5 \mu \mathrm{g} / \mathrm{ml}$ also suppressed AP-1 (Fra 1 and Jun B) activation in 4-h cultured cells. We finally examined the influence of RXM on MMP-9 mRNA expression in neutrophils. Addition of RXM into cell cultures at more than $5.0 \mu \mathrm{g} / \mathrm{ml}$ caused significant inhibition of mRNA expression, which was enhanced by LPS stimulation for $12 \mathrm{~h}$

Conclusion: These results strongly suggest that RXM inhibits neutrophil transmigration into inflammatory sites and results in favorable modification of the clinical status of inflammatory diseases.

Key words: Macrolide antibiotic, Roxithromycin, Neutrophil, Matrix metalloproteinase-9, Suppression

\section{Suppression of matrix metalloproteinase-9 production from neutrophils by a macrolide antibiotic, roxithromycin, in vitro}

\author{
Ken-Ichi Kanai ${ }^{1}$, Kazuhito Asano ${ }^{2, \mathrm{CA}}$, \\ Tadashi Hisamitsu ${ }^{2}$ and Harumi Suzaki ${ }^{1}$
}

${ }^{1}$ Department of Otolaryngology and ${ }^{2}$ Department of Physiology, School of Medicine, Showa University, 15-8 Hatanodai, Shinagawa-ku, Tokyo 142-8555, Japan

\author{
${ }^{\mathrm{CA}}$ Corresponding Author \\ Tel: +81337848110 \\ Fax: +81337845368 \\ E-mail: asanok@med.showa-u.ac.jp
}

\section{Introduction}

Low-dose and long-term use of 14-membered macrolide antibiotics (e.g. erythromycin and troleandromycin, etc.) is reported to be effective in the treatment and the management of patients with chronic airway inflammatory diseases such as diffuse panbronchiolitis (DPB) and chronic rhinosinusitis (CR). ${ }^{1-3}$ Recently, azithromycin, a newly synthesized 16-membered macrolide antibiotic, is also reported to be effective in the improvement of lung function in cystic fibrosis (CF). ${ }^{4,5}$ Although there is circumstantial evidence that the therapeutic mode of the macrolides on these inflammatory diseases may be due to their anti-inflammatory action rather than anti-microbiological effects, ${ }^{3,6}$ the precise mechanisms of this macrolide therapy are not well understood.

Accumulation of neutrophils around the small and large airways is reported to be the characteristic feature of DPB and $\mathrm{CF}^{3,7}$ Airway lavage fluids from the patients with DPB and CF commonly contain large number of inflammatory cells, especially neutrophils and high amounts of neutrophil-derived chemical mediators as well as the neutrophil granule enzyme myeloperoxidase and elastase. ${ }^{3,7,8}$ Neutrophil numbers and neutropil-derived enzymatic activity were also significantly elevated in nasal secretions from patients with CR compared with that from 
healthy subjects. ${ }^{9}$ Successful macrolide treatment is reported to cause normalization of these neutrophilic inflammatory responses along with favorable modification of clinical status of the diseases, ${ }^{2,3}$ suggesting that neutrophils play essential roles in the development of chronic airway inflammatory diseases as one of the final effector cells.

Recruitment of circulating immune cells including neutrophils into the inflammatory sites involves traversing both the capillary walls and the interstitium. ${ }^{10,11}$ To traverse these barriers, inflammatory cells adhere to endothelial cells and degrade extracellular matrix (ECM) proteins. ${ }^{10,11}$ The basement membrane is well accepted to be a unique structure composed of several types of molecules, including type IV and type V collagens, laminin and fibronectin. ${ }^{11,12}$ The degradation of ECM proteins including basement membrane proteins by monocytes/macrophages is accomplished, in part, by the secretion of the matrix metalloproteinases (MMPs) such as MMP-2 and MMP-9, which are selectively degrade type IV and type $\mathrm{V}$ collagens in their native forms. ${ }^{12}$ Recent reports showed that the inflammatory cells, such as neutrophils and eosinophils, ${ }^{13,14}$ as well as macrophages, ${ }^{11}$ secrete MMPs, especially MMP-9, to migrate through the basement membrane. In the present study, therefore, we examined the influence of macrolide antibiotics on MMP production through the choice of roxithromycin (RXM) and human peripheral blood neutrophils in vitro .

\section{Materials and methods}

\section{Reagents}

RXM was kindly donated by Aventis Pharmaceutical Co. Ltd (Tokyo, Japan) as a preservative-free pure powder. The agent was firstly dissolved in 100\% methyl alcohol at $20.0 \mathrm{mg} / \mathrm{ml}$ and then diluted with antibiotic-free RPMI-1640 medium (Sigma Chemicals Co. Ltd, St Louis, MO, USA) supplemented with 10\% heat-inactivated fetal calf serum (RPMI-FCS; Irvine Scientific, Inc., Santa Ana, CA, USA) at appropriate concentrations for experiments. Lipopolysaccharide (LPS) extracted from Klebsiella pneumoniae was purchased from Sigma Chemicals Co. Ltd and dissolved with RPMI-FCS. The basement membrane matrix (Matrigel) was purchased from Becton Dickinson Labware (Bedford, MA, USA).

\section{Preparation of neutrophils}

Heparinized human venous blood was obtained from five healthy volunteers (all male, aged 25-50 years) under written informed consent. The blood was diluted twice with phosphate-buffered saline (PBS) and overlayered onto the Mon-Poly Resolving Med- ium (Flow Laboratories, Inc., MacLean, VA, USA). After centrifugation at $1000 \times g$ for $30 \mathrm{~min}$ at $25^{\circ} \mathrm{C}$, peripheral blood leukocytes (PBL) were collected from the plasma-medium interface and washed three times with PBS. CD16 ${ }^{+}$cells, neutrophils, were separated from PBL using a magnetic cell separator (Milteny Biotec, Bergisch Gladbach, Germany) as described previously. ${ }^{15}$ In brief, PBL were labeled with human CD16 monoclonal antibodycoated magnetic beads (Milteny Biotec) and were then applied to the column placed in the separator. After removing unlabeled cells by washing with PBS, the column was removed from the separator and rinsed with PBS. The entire effluated cells were washed twice with RPMI-FCS, resuspended at a concentration of $1 \times 10^{5}$ cells $/ \mathrm{ml}$ and used as neutrophils. The purity of neutrophils was more than 97\% as judged by Giemsa's stein.

\section{Cell culture}

Neutrophils $\left(1 \times 10^{5}\right.$ cells $\left./ \mathrm{ml}\right)$ were introduced into each well of 24-well plates that contained $1.0 \mu \mathrm{g} / \mathrm{ml}$ of LPS and various concentrations of RXM in a final volume of $2.0 \mathrm{ml}$. The plates were then maintained at $37^{\circ} \mathrm{C}$ in a humidified atmosphere with $5 \% \mathrm{CO}_{2}$. The supernatant was collected $24 \mathrm{~h}$ later and stored at $-40^{\circ} \mathrm{C}$ until assayed for the levels of both MMP and tissue inhibitor of metalloproteinases (TIMP). To prepare cells examining for transcriptional factor activity and mRNA expression, neutrophils were cultured in a similar manner for $4 \mathrm{~h}$ and 12 $\mathrm{h}$, respectively. In all experiments, RXM treatment was started $1 \mathrm{~h}$ before LPS stimulation.

\section{Transmigration assay}

The migration activity of neutrophils was assessed by a kind of Boyden-chamber assay as described previously with some modifications. ${ }^{11}$ Transwell chambers fitted with polyvinylpyrolidine-free polycarbonate filters with $3.0 \mu \mathrm{m}$ pore size were used (Corning Coster Corp., Cambridge, MA, USA). Each filter was coated with $50 \mu \mathrm{l}$ of Matrigel $(200 \mu \mathrm{g})$ in RPMI-1640 medium without fetal calf serum and incubated for $1 \mathrm{~h}$ at $37^{\circ} \mathrm{C}$ to make a thin, continuous barrier on the top of the filter. Neutrophils pretreated with various concentrations of RXM for $1 \mathrm{~h}$ were seeded onto the coated membrane of the upper chamber of the Transwell at $1 \times 10^{6}$ cells in $500 \mu \mathrm{l}$ of RPMI-FCS, and stimulated with $1.0 \mu \mathrm{g} / \mathrm{ml}$ of LPS in the presence of RXM. The lower chamber was filled with $1.0 \mathrm{ml}$ of RPMI-FCS that contained the same concentration of both LPS and RXM as in the corresponding culture wells (the upper chamber). The cells were then cultured for $24 \mathrm{~h}$, and the medium was harvested from the lower chamber. The number of cells in the medium was counted 
under a microscope. The number of cells that adhered to both the bottom of the lower chamber and the lower surface of membrane was also counted.

\section{Assay for MMP-9 and TIMP-1}

MMP-9 and TIMP-1 levels in culture supernatants were examined in duplicate by commercially available MMP-9 and TIMP-1 enzyme-linked immunosorbent assay (ELISA) test kits (Amersham Biosciences Corp., Piscataway, NJ, USA) according to the manufacturer's recommendation. The sensitivity of each ELISA kit for MMP-9 and TIMP-1 was $0.6 \mathrm{ng} / \mathrm{ml}$ and $3.0 \mathrm{ng} / \mathrm{ml}$, respectively.

\section{Assay for mRNA expression}

mRNA expression was examined by means of reverse transcriptase-polymerase chain reaction (RT-PCR). Poly $\mathrm{A}^{+}$mRNA was extracted from neutrophils with MMACS mRNA isolation kits (Milteny Biotec) according to the manufacturer's instructions. The first-strand cDNA synthesis from $1.0 \mu \mathrm{g}$ of mRNA was performed with a Superscript cDNA synthesis kit (Invitrogen Corp, Carlsbad, CA, USA). Amplification of cDNA $(1.0 \mu \mathrm{l})$ was performed with a Takara PCR Amplification kit (Takara Shuzo, Co., Ltd, Shizuoka, Japan) using specific primers for MMP-9 and $\beta$-actin in a final volume of $30 \mu \mathrm{l}$. The primers used for RT-PCR were 5'-CCCACATTTGACGTCCAGAGAAGAA-3' (sense) and 5'-GTTTTTGATGCTATTGGCTGAGATCCA-3' (anti-sense) for MMP-9, and 5'-CGGAACCGCTCATTGCC-3' and 5'-ACCCACACTGTGCCCATCTA-3' for $\beta$-actin. ${ }^{16}$ The PCR conditions were as follows: 4 min at $94^{\circ} \mathrm{C}$, followed by 30 cycles of $30 \mathrm{sec}$ at $95^{\circ} \mathrm{C}$, $30 \mathrm{sec}$ at $50^{\circ} \mathrm{C}$, and $30 \mathrm{sec}$ at $70^{\circ} \mathrm{C}$. After cycling, there was a DNA extension period of $2 \mathrm{~min}$ at $70^{\circ} \mathrm{C} .{ }^{16} \mathrm{Each}$ PCR product $(10 \mu \mathrm{l})$ was run on $3 \%$ agarose gels, visualized by an ultraviolet illuminator after SYBR Green (BioWhittaker Molecular Applications, Rockland, ME, USA) staining and photographed. The intensity of mRNA levels was corrected by $\beta$-actin transcripts calculated by a densitometer.

\section{Assay for nuclear factor- $\kappa B$ and AP-1 activity}

Nuclear factor (NF) $-\kappa \mathrm{B}$ activity was analyzed by a commercially available ELISA test kit (Active Motif, Carlsbad, CA, USA) that contains sufficient reagents and monoclonal antibodies against P50 and P65 according to the manufacturer's recommended procedure. In brief, nuclear extract $(5.0 \mu \mathrm{g}$ protein) from neutrophils was introduced into each well of 96well microtiter plates pre-coated with oligonucleotide containing the NF- $\mathrm{\kappa B}$ consensus site (5'GGGACTTTCC-3') in a volume of $20.0 \mu \mathrm{l}$, and incubated for $1 \mathrm{~h}$ at $25^{\circ} \mathrm{C}$. After washing three times,
$100 \mu \mathrm{l}$ of monoclonal antibody against P50 or P65 was added to the appropriate wells, and incubated for a further $1 \mathrm{~h}$ at $25^{\circ} \mathrm{C}$. Anti-IgG horseradish peroxidase conjugate in a volume of $100 \mu$ was then added and incubated for $1 \mathrm{~h}$ at $25^{\circ} \mathrm{C}$. Absorbance at $450 \mathrm{~nm}$ was measured after the addition of tetramethylbenzine solution. AP-1 activity was also examined by a commercially available ELISA test kit (Active Motif) that contains sufficient reagents and monoclonal antibodies to Fra 1 and Jun B in a similar manner.

\section{Statistical analysis}

The statistical significance of the difference between the control and experimental data was analyzed using analysis of variance (ANOVA) followed by Fisher's PLSD test.

\section{Results}

\section{Influence of RXM on neutrophil migration}

The first experiments were undertaken to examine whether neutrophils could degrade Matrigel, which is a resembled basic membrane, and migrate through it and whether RXM could inhibit neutrophil migration. Although a Matrigel transwell filter could prevent neutrophil migration (Fig. 1, Med. alone), stimulation of neutrophils with LPS significantly enhanced the ability of cells to migrate through Matrigel (Fig. 1, LPS alone). This activity was significantly decreased by

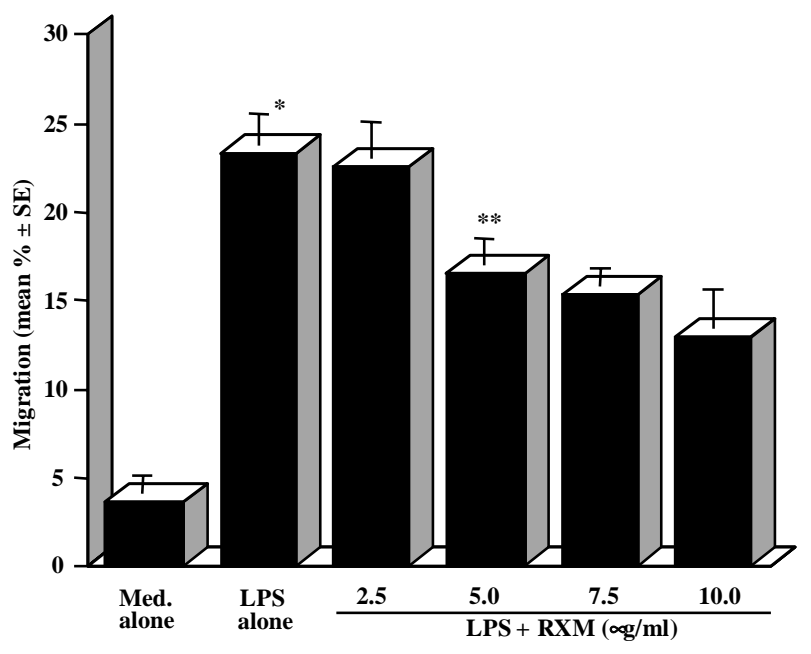

FIG. 1. Influence of RXM on neutrophil transmigration assessed by transmigration assay. Neutrophils $\left(1 \times 10^{5}\right.$ cells $/ 500 \mu \mathrm{l}$ ) stimulated with $1.0 \mu \mathrm{g} / \mathrm{ml}$ of LPS in the presence of various concentrations of RXM were added to the upper chamber. A 1-ml sample of medium was added to the lower chamber. After $24 \mathrm{~h}$, the numbers of cells transmigrated were counted. The data were expressed as mean percent neutrophil migration \pm standard error (SE) of five different subjects. *Significant $(p<0.05)$ versus medium (Med.) alone, **Significant $(p<0.05)$ versus LPS alone. 
the addition of RXM at more than $5.0 \mu \mathrm{g} / \mathrm{ml}$ into culture medium (Fig. 1).

\section{Influence of RXM on MMP-9 and TIMP-1 production from neutrophils}

The second set of experiments was designed to examine the influence of RXM on MMP-9 and TIMP-1 production from neutrophils after LPS stimulation. Neutrophils pretreated with various concentrations of RXM for $1 \mathrm{~h}$ were stimulated with $1.0 \mu \mathrm{g} / \mathrm{ml}$ of LPS in the presence of the agent for $24 \mathrm{~h}$. MMP-9 and TIMP-1 levels in culture supernatants were examined by ELISA. As shown in Fig. 2, RXM could suppress MMP-9 production from neutrophils, which was increased by LPS stimulation. This suppressive activity of RXM was first noted at $5.0 \mu \mathrm{g} / \mathrm{ml}$. On the other hand, RXM scarcely affected TIMP-1 production from neutrophils by LPS stimulation: culture supernatants obtained from cells cultured with $10.0 \mu \mathrm{g} / \mathrm{ml}$ RXM contained similar levels of TIMP-1 (not significant) to that from cells cultured without RXM (Fig. 3).

\section{Influence of RXM on MMP-9 mRNA expression in neutrophils}

The third experiment was undertaken to examine whether RXM could suppress MMP-9 mRNA expression and caused a decrease in MMP-9 levels in culture supernatants. Neutrophils pretreated with various concentrations of RXM for $1 \mathrm{~h}$ were stimulated with $1.0 \mu \mathrm{g} / \mathrm{ml}$ of LPS in the presence of the agent for $12 \mathrm{~h}$, and mRNA expression for MMP-9 was examined by

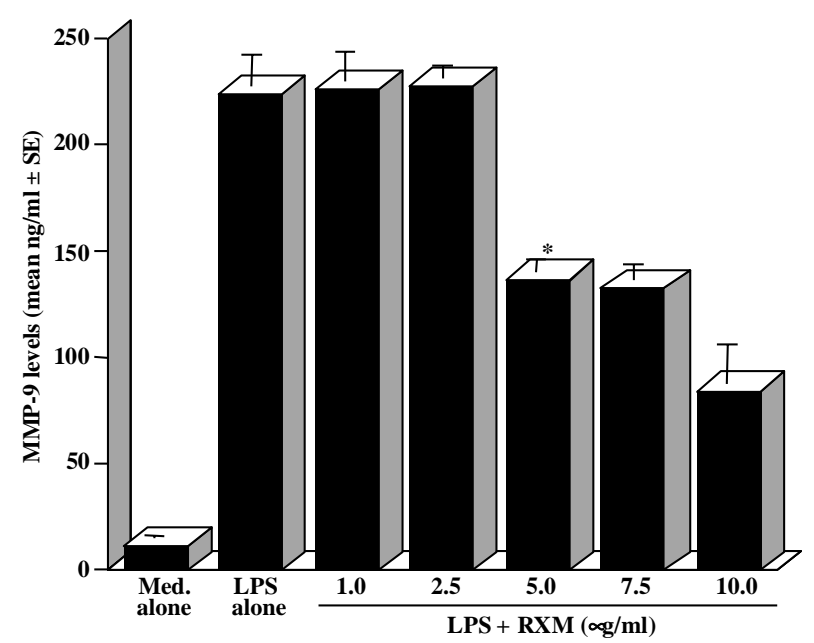

FIG. 2. Influence of RXM on MMP-9 production from neutrophils in response to LPS stimulation. Neutrophils prepared from human peripheral blood $\left(1 \times 10^{5} \mathrm{cells} / \mathrm{ml}\right)$ were stimulated with $1.0 \mu \mathrm{g} / \mathrm{ml}$ of LPS in the presence of various concentrations of RXM for $24 \mathrm{~h}$. MMP-9 levels in the culture supernatants were assayed by ELISA. The data were expressed as mean $(\mathrm{ng} / \mathrm{ml}) \pm$ standard error (SE) of five different subjects. ${ }^{*}$ Significant $(p<0.05)$ versus LPS alone. Med., medium.

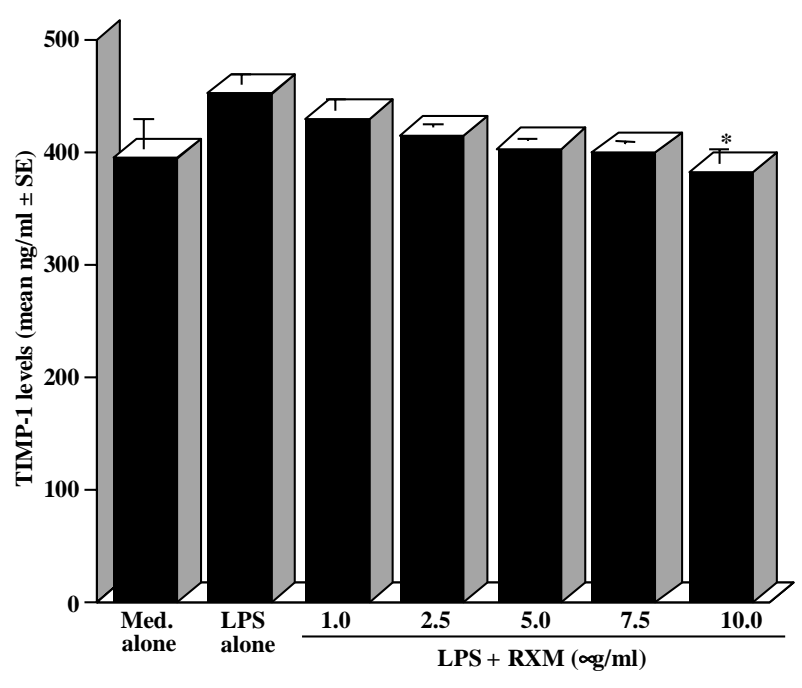

FIG. 3. Influence of RXM on TIMP-1 production from neutrophils in response to LPS stimulation. Neutrophils prepared from human peripheral blood $\left(1 \times 10^{5}\right.$ cells $\left./ \mathrm{ml}\right)$ were stimulated with $1.0 \mu \mathrm{g} / \mathrm{ml}$ of LPS in the presence of various concentrations of RXM for $24 \mathrm{~h}$. TIMP-1 levels in the culture supernatants were assayed by ELISA. The data were expressed as mean $(\mathrm{ng} / \mathrm{ml}) \pm$ standard error (SE) of five different subjects. ${ }^{*}$ Not significant $(p>0.05)$ versus LPS alone. Med., medium.

RT-PCR. The photographs in Fig. 4 clearly show that addition of RXM at more than $5.0 \mu \mathrm{g} / \mathrm{ml}$ caused inhibition of MMP-9 mRNA expression, which was
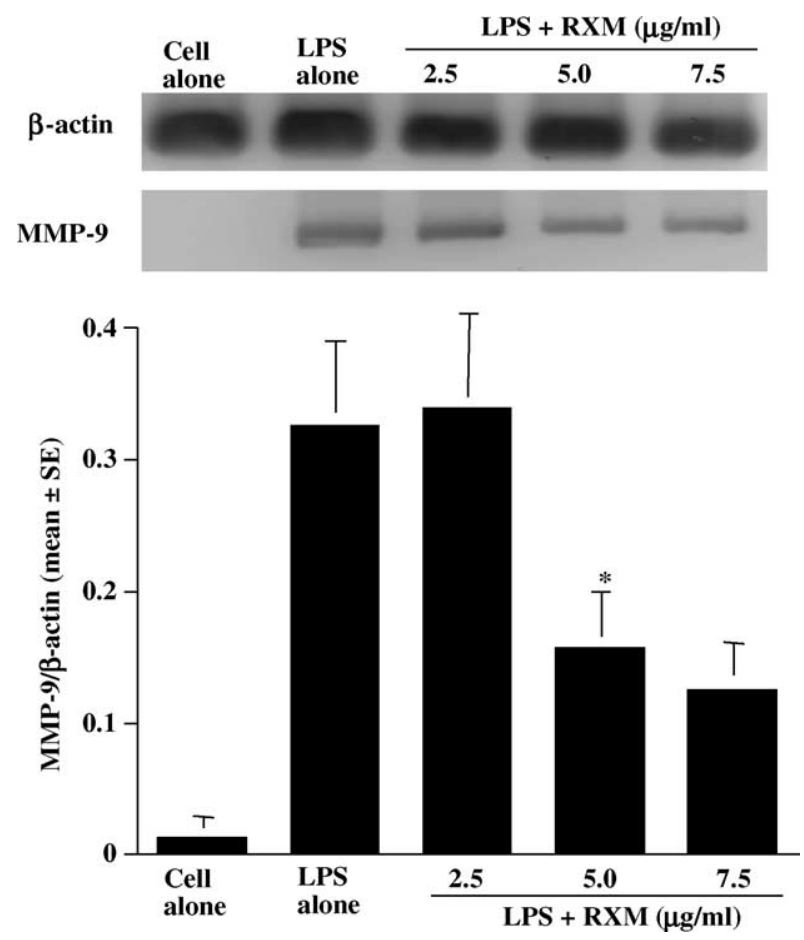

FIG. 4. Influence of RXM on MMP-9 mRNA expression in neutrophils stimulated with LPS. Neutrophils prepared from human peripheral blood $\left(1 \times 10^{5}\right.$ cells $\left./ \mathrm{ml}\right)$ were stimulated with $1.0 \mu \mathrm{g} / \mathrm{ml}$ of LPS in the presence of various concentrations of RXM for $12 \mathrm{~h}$. mRNA expression was assessed by RT-PCR. Photographs are one typical result out of five different subjects. Graphs show the ratio of MMP-9: $\beta$-actin obtained from five different subjects. ${ }^{*}$ Significant $(p<0.05)$ versus LPS alone. 
enhanced by LPS stimulation. This was confirmed by graphs showing the ratio of MMP-9/ $\beta$-actin obtained from five different subjects.

\section{Suppression of transcriptional factor activation by RXM in neutrophils}

The final set of experiments was carried out to examine the influence of RXM on transcriptional factor activity induced by LPS stimulation. Neutrophils pretreated with various concentrations of RXM for $1 \mathrm{~h}$ were stimulated with $1.0 \mu \mathrm{g} / \mathrm{ml}$ of LPS in the presence of the agent for $4 \mathrm{~h}$, and the activity of both NF- $\kappa \mathrm{B}$ and AP-1 in the nucleus was examined by ELISA. Figure 5 shows that addition of RXM at more than $5.0 \mu \mathrm{g} / \mathrm{ml}$ into cell cultures caused significant suppression of NF- $\kappa \mathrm{B}$ (P50 and P65) activity, which is enhanced by LPS stimulation. It is also showed that RXM exerts suppressive effect on AP-1 (Fra 2 and Jun B) activation induced by LPS stimulation in neutrophils (Fig. 6).

\section{Discussion}

Various studies on the action of macrolide antibiotics, especially 14-membered macrolide antibiotics, other than their antibiotic actions have been reported, ${ }^{1-6,11}$ drawing attention to the macrolides as immunomodulators. Erythromycin, the most famous macrolide antibiotic, has been reported to suppress the production of interleukin- $8^{17}$ and $\mathrm{Cl}^{-}$secretion $^{18}$ from epithelial cells. It is also reported that erythromycin and RXM exert anti-lymphocytic activity, including inhibition of inflammatory cytokine production in vitro and in vivo. ${ }^{19-22}$ We therefore considered it of great interest to examine whether macrolide antibiotics could suppress MMP gelatinolytic activity, which is an essential inducible gelatinase for monocyte/macrophage and polymorphonuclear leukocyte migration.

The present results clearly show that RXM could suppress MMP-9, but not TIMP-1, production from neutrophils induced by LPS stimulation in vitro. It is also shown that this inhibitory action of RXM may be at the transcriptional level.

Histological observations of DPB, CR and CF revealed the thickening of the basement membrane with predominant infiltration of polymorphonuclear leukocytes, especially neutrophils. ${ }^{3,7,9}$ These inflammatory changes are accompanied by edema and extend to the airway wall. ${ }^{3,7,9}$ Morphometric studies in the lungs of DPB and CF showed significant dilation of the acini of tracheal submucosal glands., It is also observed that the bronchial mucosa features excessive goblet cells and, focally, a metaplastic
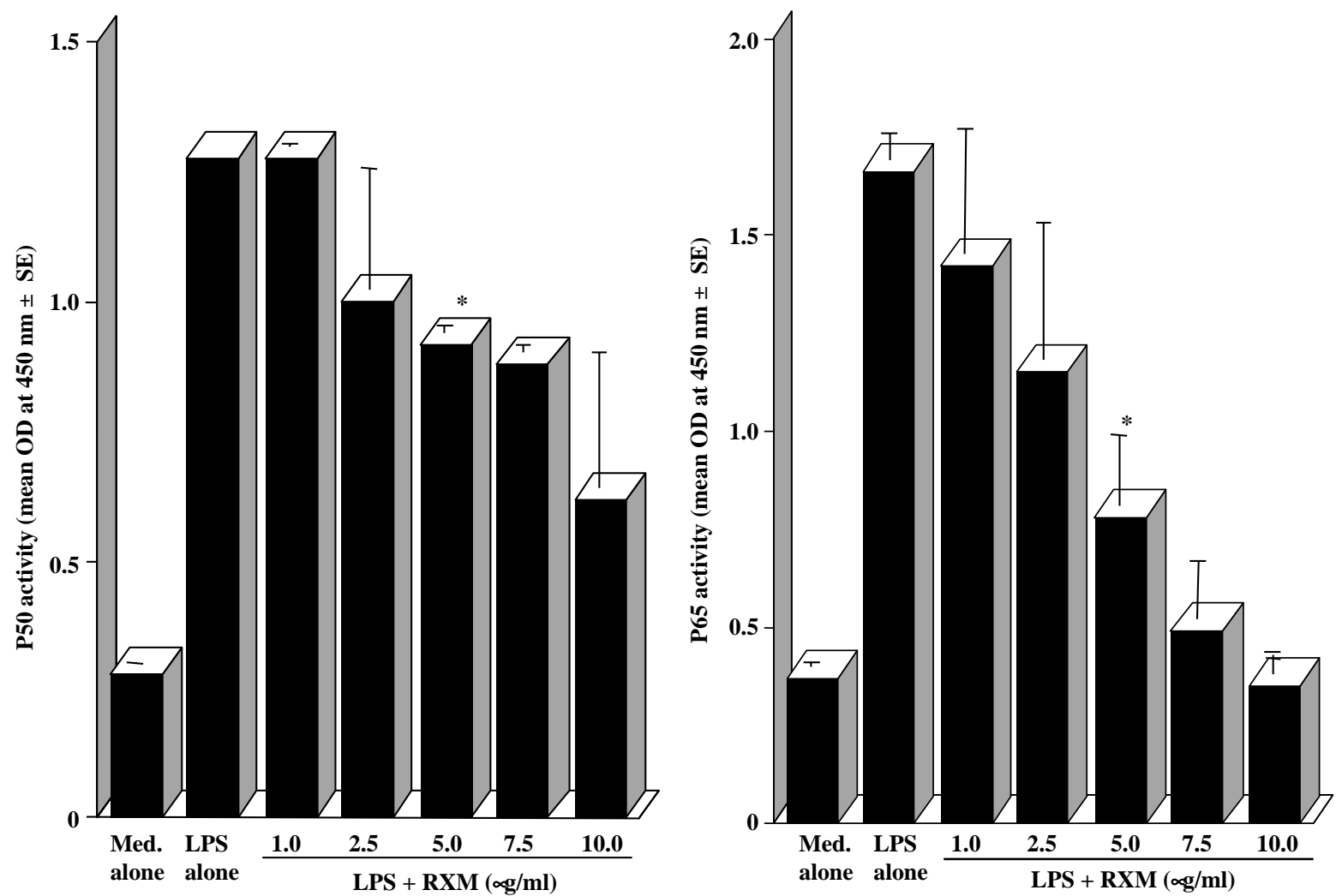

FIG. 5. Influence of RXM on NF- $\kappa B$ activation in neutrophils by LPS stimulation. Neutrophils prepared from human peripheral blood $\left(1 \times 10^{5}\right.$ cells $\left./ \mathrm{ml}\right)$ were stimulated with $1.0 \mu \mathrm{g} / \mathrm{ml}$ of LPS in the presence of various concentrations of RXM for $4 \mathrm{~h}$. NF- $\mathrm{KB}$ (P50 and P65) activity in the nucleus were assayed by ELISA. The data are expressed as the mean optical density (OD) at 450 $\mathrm{nm} \pm$ standard error (SE) of five different subjects. *Significant $(p<0.05)$ versus LPS alone. Med., medium. 

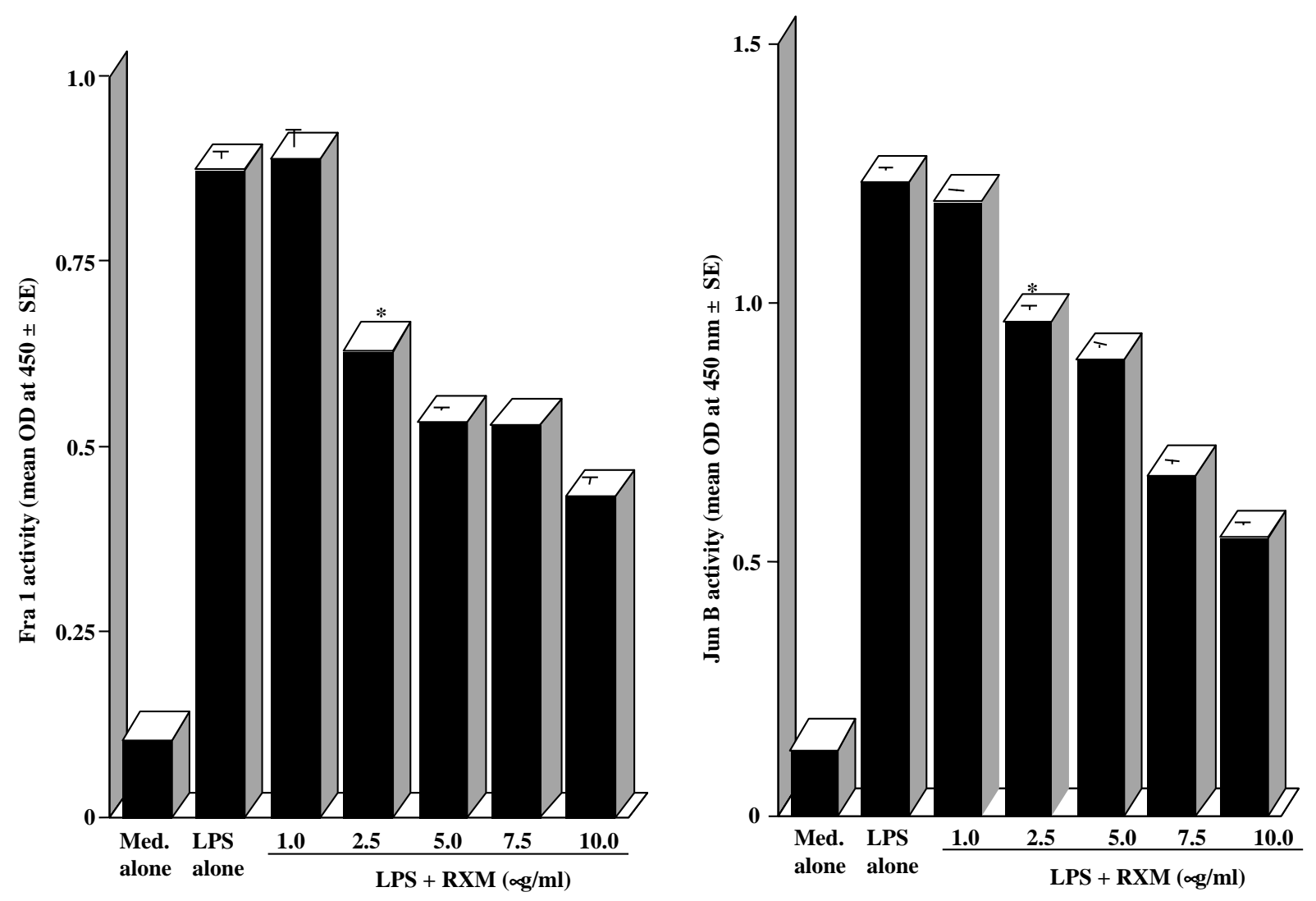

FIG. 6. Influence of RXM on AP-1 activation in neutrophils by LPS stimulation. Neutrophils prepared from human peripheral blood $\left(1 \times 10^{5}\right.$ cells $\left./ \mathrm{ml}\right)$ were stimulated with $1.0 \mu \mathrm{g} / \mathrm{ml}$ of LPS in the presence of various concentrations of RXM for $4 \mathrm{~h}$. AP-1 (Fra 1 and Jun B) activity in the nucleus was assayed by ELISA. The data are expressed as the mean optical density (OD) at 450 $\mathrm{nm} \pm$ standard error (SE) of five different subjects. ${ }^{*}$ Significant $(p<0.05)$ versus LPS alone. Med., medium.

squamous epithlium. ${ }^{3,7,23}$ In cases of CR, pathological observation showed the loss of differentiated epithelial cells ranging from denuted epithelium to basal cell hyperplasia often associated with squamous metaplasia. ${ }^{24}$ Hyperplasia and hypertrophy of nasal acinar cells in nasal mucosa were also observed. ${ }^{25}$ These histological changes are now called airway tissue remodeling, and involve extensive alterations of the tissue ECM. ${ }^{26}$

The ECM is involved in tissue homeostasis and in pathologic conditions such as tumor invasion and inflammation. ${ }^{26}$ Two groups of proteins, MMPs and their counter-regulatory inhibitors TIMPs, are accepted to be the important factors for maintenance of the ECM homeostasis. The MMPs are a large family of zinc-dependent and calcium-dependent endopeptidases with distinct substrate specificities that can degrade most components of the ECM. ${ }^{27}$ Of the MMP family, MMP-9 (named gelatinase B) is the major proteinase that induces airway remodeling. ${ }^{26}$ In addition, MMP-9 is produced by numerous cell types, including neutrophils in response to inflammatory stimulations, and is essential for the migration of neutrophils across the basement membrane to propagate inflammation. ${ }^{28,29}$ MMP-9 also appears to be responsible for microvascular permeability leading to edema and enhancement of cell transmigration. ${ }^{28,29}$
From these reports, it is possible that the inhibitory action of RXM on MMP-9 production from neutrophils may be one of therapeutic mechanisms of RXM on chronic airway diseases. This suggestion may be supported by the observation that erythromycin could suppress the ability of U937, a human histiocytic lymphoma cell line, to produce MMP-9 in vitro and also inhibited transmigration of $\mathrm{U} 937$ cells through a $12 \mu \mathrm{m}$ pore size filter coated with laminin and type IV collagen. ${ }^{11}$

Most MMPs are secreted from the cells as inactive proenzymes and cleaved extracellularly to produce the active forms. ${ }^{30}$ The extracellular activity of MMPs is regulated by TIMPs, which are secreted by the same cell types that produce MMPs. ${ }^{30}$ The present results clearly showed that RXM scarcely affected the ability of neutrophils to produce TIMP-1, suggesting that MMP-9 secreted in small amounts during RXM treatment is inactivated by TIMP-1, and results in the inhibition of ECM remodeling and inflammatory responses.

Previous studies clearly showed that the production of several mediators (e.g. inflammatory cytokines and chemokines) and various lytic enzymes by neutrophils is typically preceded by an accumulation of the corresponding mRNA transcripts, ${ }^{31,32}$ which largely depend on several types of transcriptional 
factor activation. ${ }^{32}$ Among them, transcriptional factors, NF- $\kappa \mathrm{B}$ and $\mathrm{AP}-1$ are widely recognized as central regulators in neutrophil activation induced by LPS and tumor necrosis factor-alpha stimulation. ${ }^{17,32}$ It is also recognized that MMP production requires the translocation of both NF- $\kappa \mathrm{B}$ and $\mathrm{AP}-1$ to the nucleus and binding to promoter regions, which cause the induction of MMP mRNA expression. ${ }^{33,34}$ These reports prompt us to examine the influence of RXM on NF- $\kappa \mathrm{B}$ and AP-1 activation, which may influence the expression of MMP-9 mRNA by interacting with the promoter region of the gene. The present results clearly showed that RXM at a concentration of $5.0 \mu \mathrm{g} / \mathrm{ml}$ could suppress mRNA expression for MMP9 through the inhibition of transcriptional factor, NF$\kappa \mathrm{B}$ and AP-1, activation induced by LPS stimulation.

Since the concentration of RXM $(5.0 \mu \mathrm{g} / \mathrm{ml})$ showing the suppressive effect on MMP-9 production in vitro is far below that in plasma levels $(7.5-10.0 \mu \mathrm{g} / \mathrm{ml})$ in the macrolide therapy, ${ }^{21,22}$ the efficacy of 14-membered macrolide antibiotics, especially RXM, in chronic airway inflammatory diseases may be explained by these in vitro data suggesting downregulating activity of the drugs on neutrophil functions related to inflammation and tissue remodeling.

\section{References}

1. Iino Y, Toriyama M, Kudo K, Narita Y, Yuo A. Erythromycin inhibition of lipopolisaccharide-stimulated tumor necrosis factor alpha production by human monocytes in vitro. Ann Otol Rhinol Laryngol 1992; 101(Suppl 157): $16-20$

2. Kadota J, Sakito O, Kohno S, et al. A mechanism of erythromycin treatment in patients with diffuse panbronchiolitis. Am Rev Respir Dis 1993; 147: 153-159.

3. Keicho N, Kudoh S. Diffuse panbronchiolitis - role of macrolides in therapy. Am J Respir Med 2002; 1: 119-131.

4. Jaffe A, Francis J, Rosenthal M, Bush A. Long-term azithromycin may improve lung function in children with cystic fibrosis. Lancet 1998; 351 : 420.

5. Pirzada OM, Taylor CJ. Long term macrolide antibiotics improve pulmonary function in cystic fibrosis. Pediatr Pulmonary 1999; 19 (Suppl): 283

6. Jaffe A, Bush A. Anti-inflammatory effects of macrolides in lung disease. Pediatr Pulmonary 2001; 31: 464-473.

7. Tomashefski JF, Abramowsky CR, Dahms BB. The pathology of cystic fibrosis. In: Davis PB, ed. Cystic Fibrosis, New York: Marcel Dekker, 1993: 435-489

8. Van der Vlite A, Nguyen MN, Shigenaga MK, Eiserich JP, Marelich GP, Cross CE. Myeloperoxidase and protein oxidation in cystic fibrosis. Am J Physiol Lung Cell Mol Physiol 2000; 279: L537-L546.

9. Lee HS, Majima Y. Quantitative cytology of nasal secretions under various conditions. Laryngoscope 1993; 103: 533-537.

10. Vestwever D, Blanks JE. Mechanisms that regulate the function of the selectines and their ligands. Physiol Rev 1999; 79: 181-213.

11. Hashimoto N, Kawabe T, Hara T, et al. Effect of erythromycin on matrix metalloproteinase-9 and cell migration. J Lab Clin Med 2001; 137: 176183.

12. Mignatti $P$, Rifkin DB. Biology and biochemistry of proteinases in tumor invasion. Physiol Rev 1993; 73: 161-195.
13. Delclaux C, Delacourt C, D'Ortho MP, Boyer V, Lafuma C, Harf A. Role of gelatinase $\mathrm{B}$ and elastase in human polymorphonuclear neutrophil migration across basement membrane. Am J Respir Cell Mol Biol 1996; 14: $288-295$.

14. Okada S, Kita H, George TJ, Gleich GJ, Leiferman KM. Migration of eosinophils through basement membrane components in vitro: role of matrix metalloproteinase-9. Am J Respir Cell Mol Biol 1997; 17: 519528.

15. Ito J, Asano K, Tryka E, Kanai K, Yamamoto S, Hisamitsu T, Suzaki H. Suppressive activity of co-stimulatory molecule expressions on mouse splenocytes by anti-allergic agents in vitro. Mediat Inflamm 2000; 9: $69-75$

16. Cataldo DD, Tournoy KG, Vermaelen K, et al. Matrix metalloproteinase9 deficiency impairs cellular infiltration and bronchial hyperresponsiveness during allergen-induced airway inflammation. Am J Pathol 2002; 161: $491-498$.

17. Desaki M, Takizawa H, Ohtoshi T, et al. Erythromycin suppresses nuclear factor- $\mathrm{\kappa B}$ and activator protein-1 activation in human bronchial epithelial cells. Biochem Biophys Res Commun 2000; 267: 124-128.

18. Tamaoki J, Isono K, Sakai N, Kanemura T, Konno K. Erythromycin inhibits $\mathrm{Cl}$ secretion across canine tracheal epithelial cells. Eur Respir J 1992; 5: 234-238.

19. Keicho N, Kudoh S, Yotsumoto H, Akagawa K. Antilymphocyic activity of erythromycin distinct from that of FK-506 or cyclosporin A. J Antibiot 1992; 47: 1406-1413.

20. Suzaki H, Asano K, Ohki S, Kanai K, Mizutani T, Hisamitsu T. Suppressive activity of a macrolide antibiotic, roxithromycin, on proinflammatory cytokine production in vitro and in vivo. Mediat Inflamm 1999; 8: 199-204.

21. Asano K, Kamakazu K, Hisamitsu T, Suzaki H. Modulation of Th2 type cytokine production from human peripheral blood leukocytes by a macrolide antibiotic, roxithromycin, in vitro. Int Immunopharmac 2001; 1: 1913-1921.

22. Noma T, Aoki K, Hayashi M, Yoshizaki I, Kawano Y. Effect of roxithromycin on $\mathrm{T}$ lymphocyte proliferation and cytokine production elicited by mite antigen. Int Immunopharmac 2001; 1: 201-210.

23. Tirouvanziam R, Khazaal I, Peault B. Primary inflammation in human cystic fibrosis small airways. Am J Physiol Lung Cell Mol Physiol 2002; 283: L445-L 451.

24. Al-Rawi MM, Edelstein DR, Erlandson RA. Changes in nasal epithelium in patients with severe chronic sinusitis: a clinicopathologic and electron microscopic study. Laryngoscope 1998; 108: 1816-1823.

25. Majima Y, Masuda S, Sakakura Y. Quantitative study of nasal secretory cells in normal subjects and patients with chronic sinusitis. Laryngoscope 1997; 107: 1515-1518.

26. Atkins JJ, Senior RM. Matrix metalloproteinase-9 in lung remodeling. Am J Respir Cell Mol Biol 2003; 28: 12-24.

27. Stetler-Stevenson WG. Dynamics of matrix turnover during pathologic remodeling of the extracellular matrix. Am J Pathol 1996; 148: $1345-$ 1350 .

28. Herouy Y, Mellios P, Bandemir E, Dichmann S, Nockowski P, Schopf E. Inflammation in stasis dermatitis upregulates MMP-1, MMP-2 and MMP13 expression. J Dermatol Sci 2001; 25: 98-205.

29. Ohno I, Ohtani H, Nitta Y. Eosinophils as a source of matrix metalloproteinase-9 in asthmatic airway inflammation. Am J Respir Cell Mol Biol 1997; 16: 212-219.

30. Birkedal-Hansen H, Moore WG, Bodden MK. Matrix metalloproteinases: a review. Crit Rev Oral Biol Med 1993; 4: 197-250.

31. Cassatella MA. Neutrophil-derived proteins: selling cytokines by the pound. Adv Immunol 1999; 73: 369-509.

32. Cloutier A, McDonald PP. Transcription factor activation in human neutrophils. In: Cassatella MA, ed. The Neutrophil, Basel: Karger, 2003: $1-23$.

33. Wasylyk C, Gutman A, Nicholson R, Wasylyk B. The c-Ets oncoprotein activates the stromelysin promoter through the same elements as several non-nuclear oncoprotein. EMBO J 1991; 10: 1127-1134.

34. Sato H, Seiki M. Regulatory mechanism of $92 \mathrm{kDa}$ type IV collagenase gene expression which is associated with invasiveness of tumor cells. Oncogene 1993; 8: 395-405.

\section{Received 19 May 2004 \\ Accepted 7 July 2004}




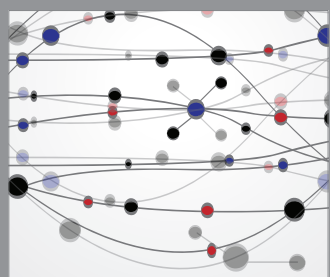

The Scientific World Journal
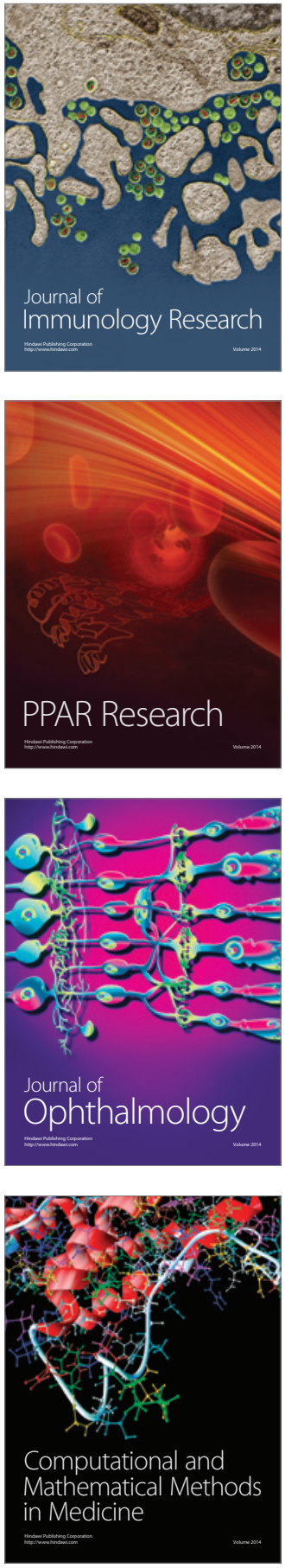

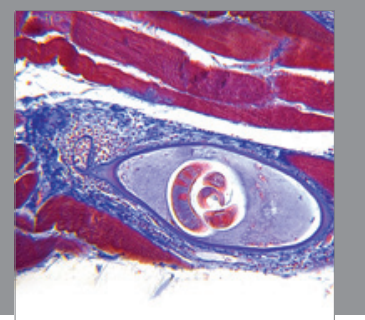

Gastroenterology

Research and Practice
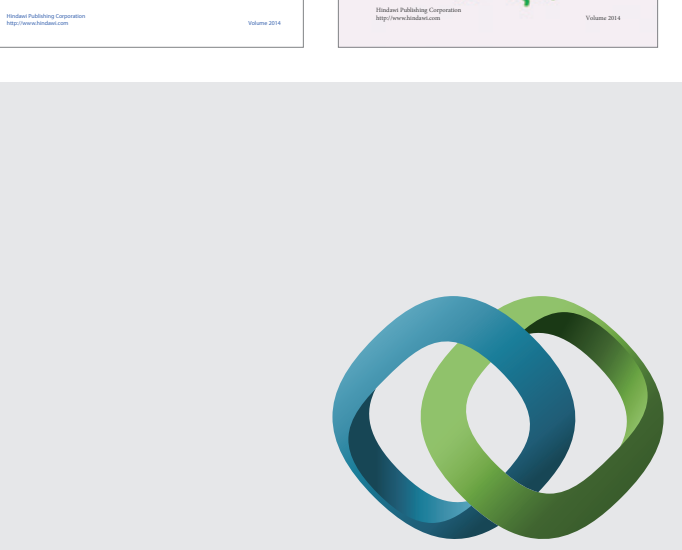

\section{Hindawi}

Submit your manuscripts at

http://www.hindawi.com
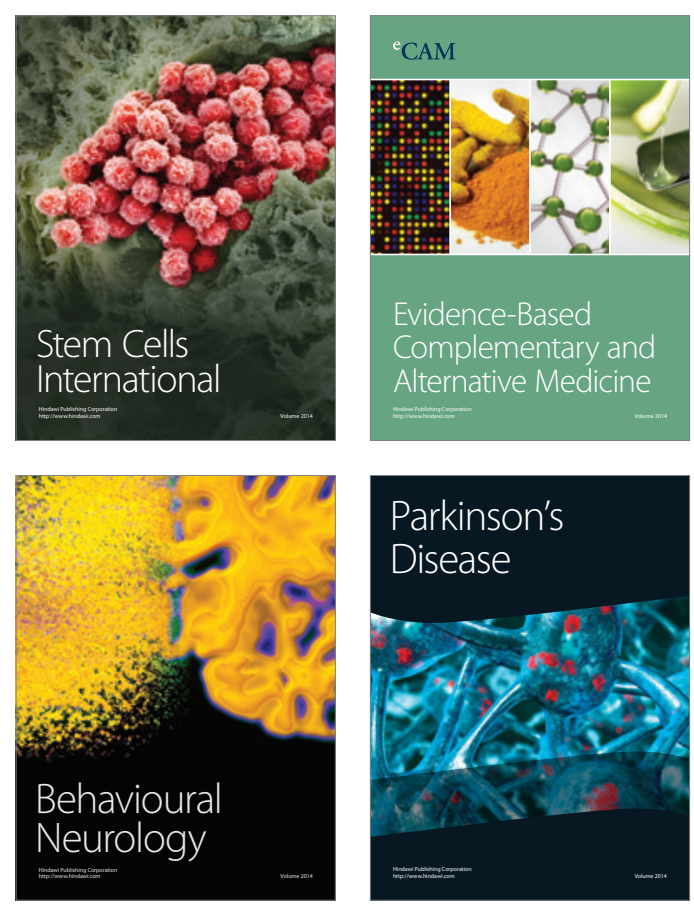

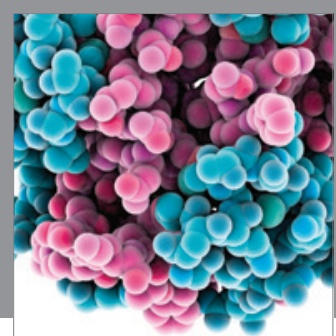

Journal of
Diabetes Research

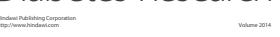

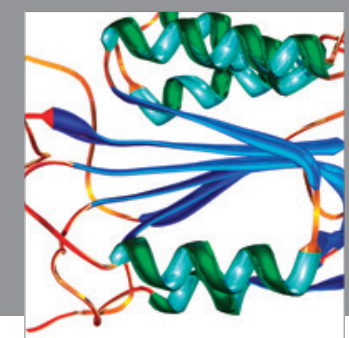

Disease Markers
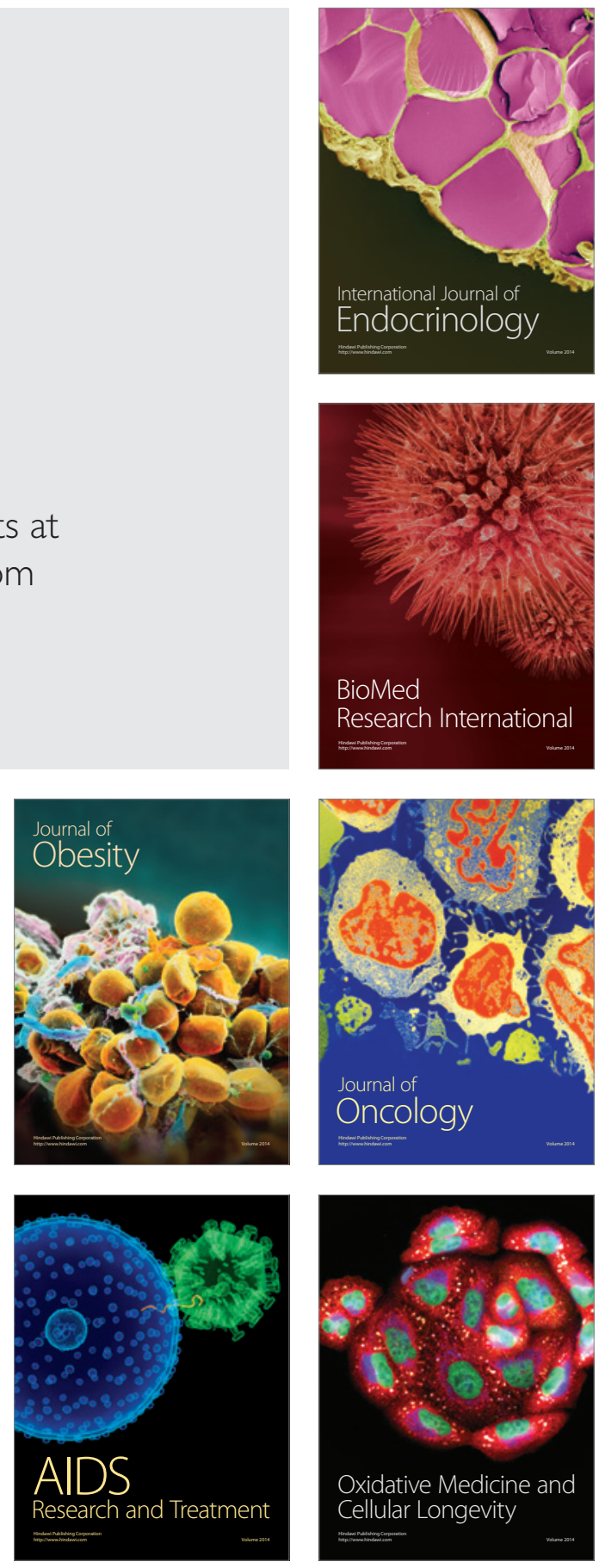